\title{
Proteomic profile of Piper tuberculatum (Piperaceae)
}

\author{
F. Cotinguiba ${ }^{a, b *}$, S. N. López ${ }^{c}$, I. G. F. Budzinskid, C. A. Labate ${ }^{d}$, M. J. Kato ${ }^{e}$ and M. Furlan ${ }^{b}$
}

aPrograma de Pós-graduação em Química de Produtos Naturais, Instituto de Pesquisas de Produtos Naturais - IPPN, Universidade Federal do Rio de Janeiro - UFRJ, Av. Carlos Chagas Filho, 373, Bloco H, Ilha do Fundão, CEP 21941-902, Rio de Janeiro, RJ, Brazil

'Programa de Pós-graduação em Química, Instituto de Química, Universidade Estadual Paulista - UNESP, Av. Prof. Francisco Degni, 55, Jardim Quitandinha, CEP 14800-900, Araraquara, SP, Brazil

${ }^{\circ}$ Farmacognosia, Facultad de Ciencias Bioquímicas y Farmacéuticas, Universidad Nacional de Rosario - UNR, Suipacha 531, S2002LRK, Rosario, Santa Fe, Argentina

'Programa de Pós-graduação em Genética, Departamento de Genética, Escola Superior de Agricultura “Luiz de Queiroz" ESALQ, Universidade de São Paulo - USP, Av. Pádua Dias, 11, Bairro São Dimas, CEP 13400-970, Piracicaba, SP, Brazil 'Programa de Pós-graduação em Química, Instituto de Química, Universidade de São Paulo - USP, Av. Prof. Lineu Prestes, 748, Cidade Universitária, CEP 05508-000, São Paulo, SP, Brazil

*e-mail: fernando@nppn.ufrj.br

Received: May 30, 2016 - Accepted: September 11, 2016 - Distributed: February 28, 2018

(With 1 figure)

\begin{abstract}
Piper tuberculatum (Piperaceae) is a species that accumulates especially amides as secondary metabolites and several biological activities was previously reported. In this article, we report a proteomic study of $P$. tuberculatum. Bidimensional electrophoresis (2D SDS-PAGE) and mass spectrometry (ESI-Q-TOF) were used in this study. Over a hundred spots and various peptides were identified in this species and the putative functions of these peptides related to defense mechanism as biotic and abiotic stress were assigned. The information presented extend the range of molecular information of $P$. tuberculatum.
\end{abstract}

Keywords: Piperaceae, amidas, Piper tuberculatum, proteomics, 2D-SDS-PAGE.

\section{Perfil proteômico e metabólico de Piper tuberculatum (Piperaceae)}

\section{Resumo}

Piper tuberculatum (Piperaceae) é uma espécie que acumula especialmente amidas como metabólitos secundários e diversas atividades biológicas dessa espécie foram relatadas anteriormente. No presente artigo, relatamos um estudo proteômico dessa espécie. Eletroforese bidimensional (2D SDS-PAGE) e espectrometria de massas (ESI-Q-TOF) foram utilizadas nesse estudos. Mais de cem spots e vários peptídeos foram identificados nesta espécie e as funções putativas desses peptídeos relacionadas a mecanismo de defesa como estresse biótico e abiótico foram atribuídos. As informações apresentadas ampliam a gama de informações moleculares dessa espécie.

Palavras-chave: Piperaceae, amides, Piper tuberculatum, proteômica, 2D SDS-PAGE.

\section{Introduction}

The field of plant proteomics has progressed significantly in recent years. With this has come a disproportionately larger growth in the amount of available information from databases when compared to that available for other organisms (Remmerie et al., 2011). That said, most of the data are derived from a small subset of economically important crops, such as rice, wheat and grapes, as well as from Arabidopsis thaliana. While the latter's proteome is reasonably well characterized, the number of proteins identified remains small considering over 27.000 protein-coding genes are predicted from its genome data (Baerenfaller et al., 2008; Giavalisco et al., 2005). A comprehensive study carried out on A. thaliana organs resulted in a proteome map of roots, young leaves, cotyledons, seed pod, flowers, buds, flowers carpels and undifferentiated cells. So far, 13.029 proteins, which represent about $50 \%$ out of the predicted genes, have been identified. This data set has helped to isolate specific biomarkers for each organ, which in turn has allowed the correlation between the level of transcription, protein accumulation and compartmentalization of metabolic pathways (Baginsky et al., 2005; Bussell et al., 2013).

Current approaches, such as, genomics, transcriptomics, proteomics and metabolomics, that focus on systems biology are providing new data about the genes and enzymes 
involved in several metabolic pathways. These global studies, however, are still scarce for tropical and wild plants, which represents $2 / 3$ of the total of World's green plants and are one of the most important, still largely untapped, repository of chemical structures important for pharmaceutical and cosmetic applications, as well as, for example, forestry and agronomy (Balbuena et al., 2011). Piper nigrum (black pepper), considered the "King of Spices" because of its economic importance and its ubiquitous culinary presence, had its transcriptome data from leaves and roots recently described (Gordo et al., 2012; Joy et al., 2013).

The Piperaceae family is placed amongst primitive Angiosperms and comprises more than 4000 species in tropical and subtropical regions with five genera: Peperomia Ruiz and Pavon (about 1700 species), Piper L. (about 2000 species), Manekia ret. (formerly called Sarcorhachis), Verhuellia and Zippelia (Wanke et al., 2007).

$P$. tuberculatum produces especially amides as secondary metabolites (Figure 1, compounds 1-5) and several of these compounds have displayed interesting biological properties, including antifungal, insecticidal, apoptotic cancer cell death and trypanocidal activities (Cotinguiba et al., 2009; Navickiene et al., 2000; Raj et al., 2011; Silva et al., 2002).

Protein fractions from leaves and fruits of $P$. tuberculatum were analyzed it aimed to supplement the existing proteomics information about tropical and non-model species. We characterized part of the proteome of both fruits and leaves of by 2D-SDS-PAGE and mass spectrometry (ESI-Q-TOF).

\section{Methods}

\subsection{Plant material}

Tissue samples (leaves and fruits) were harvested from adult specimens of $P$. tuberculatum in September, 2009. The plants were growing in field $\left(21^{\circ} 48^{\prime} 26.62^{\prime \prime}\right.$ $\mathrm{S} 48^{\circ} 11^{\prime} 33.51$ ” W; $651 \mathrm{~m}$ ) at the Institute of Chemistry at Araraquara (Universidade Estadual Paulista, UNESP). The specie was identified by Dr. Guillermo E. D. Paredes (Universidad Pedro Ruiz Gallo, Lambayeque, Peru) and the voucher (Kato-163) were deposited at the Herbarium of the Institute of Biosciences, USP, São Paulo-SP, Brazil.

\subsection{Protein extraction}

The protein fractions were obtained according to Durst et al. (1996), with few modifications. The tissues (20 g) were ground to a fine powder in liquid nitrogen, and homogenized in $100 \mathrm{~mL}$ of extraction buffer $(250 \mathrm{mM}$ sucrose, $1 \mathrm{mM}$ EDTA, $1 \mathrm{mM}$ DTT, $40 \mathrm{mM}$ sodium ascorbate, $10 \%$ glycerol and $4 \mathrm{~g}$ polyvinylpolypyrrolidone in $0.1 \mathrm{M} \mathrm{PBS}, \mathrm{pH}$ 7.4), by shaking at $4{ }^{\circ} \mathrm{C}$ for 10 minutes. After centrifugation $\left(10,000 \times g\right.$ for 15 minutes at $\left.4{ }^{\circ} \mathrm{C}\right)$ the supernatant was separated and a solution $1 \mathrm{M}$ of $\mathrm{MgCl}_{2}$ was added to give a final concentration of $30 \mathrm{mM}$. This solution was stirred for 20 minutes at $4{ }^{\circ} \mathrm{C}$ and centrifuged at $40,000 \mathrm{x}$. The pellet was dried and resuspended in $1 \mathrm{~mL}$ of $0.1 \mathrm{M}$ PBS. This sample and the supernatant were used as protein sources after determination of protein concentration employing Bradford method (Bradford, 1976).

\section{3. $2-D E$}

The 2-DE with immobilized $\mathrm{pH}$ gradients (IPG-Dalt) was carried out according to the supplier information (GE Healthcare ${ }^{\circledR}$ ). The IPG strips $(13 \mathrm{~cm}$ ) were rehydrated for 16 hours with sample of proteins $(5 \mu \mathrm{g}$ of protein $/ \mu \mathrm{L}$ ) previously treated with the 2D Clean-Up Kit (GE Healthcare ${ }^{\circledR}$ ) in an Immobiline DryStrip Reswelling Tray. The first dimension isoelectric focusing (IEF) was carried out in an Ettan IPGphor II Manifold applying a manufacturer's standard protocol with some modifications (strips were pre-focused at $500 \mathrm{~V}$ for 1 hour, $1,000 \mathrm{~V}$ for 1 hour and $8,000 \mathrm{~V}$ for 7 hours). The second dimension was performed on a vertical $12 \%$ polyacrylamide SDS gel $(14 \times 16 \mathrm{~cm})$, in a SE 600 Ruby System, 45 mA/gel and 600 V. Proteins were stained using Coomassie Brilliant Blue G-250 after fixation with a $10 \%(\mathrm{v} / \mathrm{v})$ acetic acid and $40 \%$ ethanol for 1 hour. The gels were scanned and analyzed with Image Master 5.0 software (Amersham Bioscience), in which the isoelectric point (pI) and an apparent molecular mass $\left(M_{r}\right)$ for spots were assigned. Each spot was extracted with a scalpel, cut into segments of approximately $1 \mathrm{~mm}^{3}$<smiles>O=C(/C=C/C=C/c1ccc2c(c1)OCO2)N1CCCCC1</smiles><smiles>CC(C)CNC(=O)/C=C/C=C/c1ccc2c(c1)OCO2</smiles><smiles>CC(C)CNC(=O)/C=C/c1ccc2c(c1)OCO2</smiles><smiles>CCN(C(C)=O)C(=O)/C=C/c1cc(OC)c(OC)c(OC)c1</smiles><smiles>CCCCC/C=C/C=C/C(=O)NCC(C)C</smiles>

Figure 1. Antifungal metabolites isolated from Piper tuberculatum: piperine (1), piperlonguminine (2), fagaramide (3), (E)-piplartine (4) and pellitorine (5). 
and stored in $1 \%$ acetic acid at $4{ }^{\circ} \mathrm{C}$. The gel segments were washed thrice in a solution containing $50 \%(\mathrm{v} / \mathrm{v})$ acetonitrile and $25 \mathrm{mM}$ ammonium bicarbonate (AMBIC) for 30 minutes until the gel became colorless. Then, the samples were dehydrated twice with $100 \%$ acetonitrile for 10 minutes. The acetonitrile was removed and the remaining residue was evaporated from the gel at room temperature. The gel fragments were rehydrated and reduced by dithiothreitol (DTT) $(20 \mathrm{mM}$ DTT/AMBIC $50 \mathrm{mM})$ at $56{ }^{\circ} \mathrm{C}$ and alkylated for 40 minutes with iodoacetamide (IAA) (55 mM IAA/AMBIC $50 \mathrm{mM}$ ) in darkness for 30 minutes. The iodoacetamide was removed and the fragments were washed with $25 \mathrm{mM}$ AMBIC and then dehydrated in $100 \%$ acetonitrile. The acetonitrile was discarded and the residue remaining in the gel was allowed to evaporate at room temperature. Gel fragments were rehydrated with $15 \mu \mathrm{L}$ solution containing $150 \mathrm{ng}$ of trypsin in $25 \mathrm{mM}$ AMBIC. After 15 minutes, $25 \mathrm{mM}$ AMBIC was added to cover spots and was maintained at $37{ }^{\circ} \mathrm{C}$ for 14 hours. The reaction was stopped by adding $15 \mu \mathrm{L}$ of blocking solution (50\% v/v acetonitrile and $5 \%$ $\mathrm{v} / \mathrm{v}$ formic acid). Peptides were eluted from acrylamide with three washes of 15 minutes with eluting solution $(50 \% \mathrm{v} / \mathrm{v}$ acetonitrile, and $1 \% \mathrm{v} / \mathrm{v}$ formic acid) and two washes with $100 \%$ acetonitrile at $40{ }^{\circ} \mathrm{C}$ in an ultrasound bath. The solution containing the peptides was dried in a Speed Vac concentrator type (Thermo Scientific). After drying the peptides were resuspended in $12 \mu \mathrm{L}$ of formic acid $1 \%(\mathrm{v} / \mathrm{v})$ for further storage. Prior to MS/MS analysis, the mixtures were purified using ZipTips mini-columns $\left(\mathrm{C}_{18}\right)$ eluted with acetonitrile (mixed with TFA $0.1 \%$ in ultrapure water), $0.1 \%$ TFA in ultrapure water and methanol 5\% $(0.1 \%$ TFA in ultrapure water) (Celedon et al., 2007).

\subsection{Mass spectrometry analysis}

Peptide mixtures were analyzed by liquid chromatography using a Cap-LC coupled to a mass spectrometer Q-TOF Ultima API (Waters, England). Ten microliters of each sample were submitted to a pre-column $\left(\mathrm{C}_{18}, 5 \mu \mathrm{m}\right.$, 5 X $30 \mathrm{~mm}$, Waters ${ }^{\circledR}$ ) for pre-concentration and desalting. Then the peptides were separated in a column (Symmetry $\mathrm{C}_{18}, 5 \mu \mathrm{m}, 32 \times$

$150 \mathrm{~mm}$, Waters $\left.{ }^{\circledR}\right)$ and eluted using a linear gradient of $10-45 \%$ solvent B ( $95 \%$ acetonitrile, $0.1 \%$ FA in water) in Solvent A ( $5 \%$ acetonitrile and $0.1 \% \mathrm{FA}$ in water) at a flow rate of $5 \mathrm{~mL} /$ minute for the first 15 minutes, changing to $2 \mathrm{~mL} /$ minute for the next 25 minutes, and finally to $5 \mathrm{~mL} /$ minute during the last 5 minutes. All MS analyzes were performed using the positive ion mode (voltage of $3 \mathrm{kV}$ ) between $\mathrm{m} / \mathrm{z} 300$ and 2000, and the spectra of MS/MS were acquired for the most intense peaks, with at least 15 points (Celedon et al., 2007).

\subsection{Data processing}

MS/MS-ion database searches were carried out by Mascot on line in the web. Peptides were searched in the Viridiplanteae ESTs from the NCBI (tblastn) and the resulting nucleotide sequences were annotated using the
NCBI data base (blastx). Search parameters used were: Database: NCBI; Enzyme: Trypsin; Allow up to: 1 missed clivage; Quantification: none; Taxonomy: Viridiplanteae (Green plants); Fixed Modifications: Carbamidomethyl (C); Variable Modifications: Oxidation (M); Peptide Tolerance: $50 \mathrm{ppm}$; MS/MS tolerance: 0.6 Da; Peptide charge: $+2+3+4$; Data format: PKL; Instrument: ESI-Q-TOF. For each combination of peptides, the Mascot provides an index of protein, termed protein score, $[-10 * \log (\mathrm{P})]$, where $P$ is the probability that the set of identified peptides is observed in a random event. Protein score values above 60 were considered significant $(\mathrm{p}<0.05)$ and the higher these values, were considered as reliable. The values of relative molecular mass $\left(\mathrm{M}_{\mathrm{r}}\right)$ and isoelectric points $(\mathrm{pI})$ were also provided and these values were compared to those obtained experimentally. If the amount of protein for identity score protein is highly reliable, but the masses are not equal, it can be resulting from a post-translational modification or cleavage event. The total measured ion score provides information on how well the spectrum MS/MS provides the identity of the combination of peptides. The confidence limit for total ion score is the same as for the protein score. The value indicates the probability that the observed set between MS/MS spectra and sequence peptide results from the same protein/peptide. The identity of the peptide (ID) number is given by gi (genInfo identifier) which is a unique number that identifies a full and particular exact sequence. The coverage (coverage protein) indicates the percentage of residues in each protein sequence that was identified when compared to the peptide bank (Table 1). Peptides with "no identity" are those with no similarity to any other peptide sequences in the NCBI database.

\section{Results}

The 2-DE gels from $P$. tuberculatum proteins yielded more than 300 proteins spots. It was possible to remove from the gel only some of them. These spots were analyzed by MS (ESI-Q-TOF) and several proteins/enzymes involved in primary and secondary metabolism and other events were characterized (Table 1). Both gels were visually inspected, and spots in the rage of $14-90 \mathrm{kDa}$ were observed. The amount of spots in the leaf extract for both species was higher than in the fruits, accounted by the high concentration of enzymes involved in basal metabolism as fixation of carbon dioxide in leaves.

The proteins characterized in each organ of each species were classified into six main biological processes, as described by Rison et al. (2000) and modified by Celedon et al. (2007). The analysis reveals that in $P$. tuberculatum leaves, the Metabolism and Energy category were the most abundant (39\%) follow by Cellular Processes (21\%). The 50\% remaining are involved in Protein Transport and Signaling (3\%), Structure and Organization (11\%), Information Pathway (11\%), Miscellaneous (4\%) and No Identity when confronted to the database (7\%). Regarding $P$. tuberculatum fruits, the proteins were characterized as belonging to Metabolic Processes (27\%); Cellular Processes 


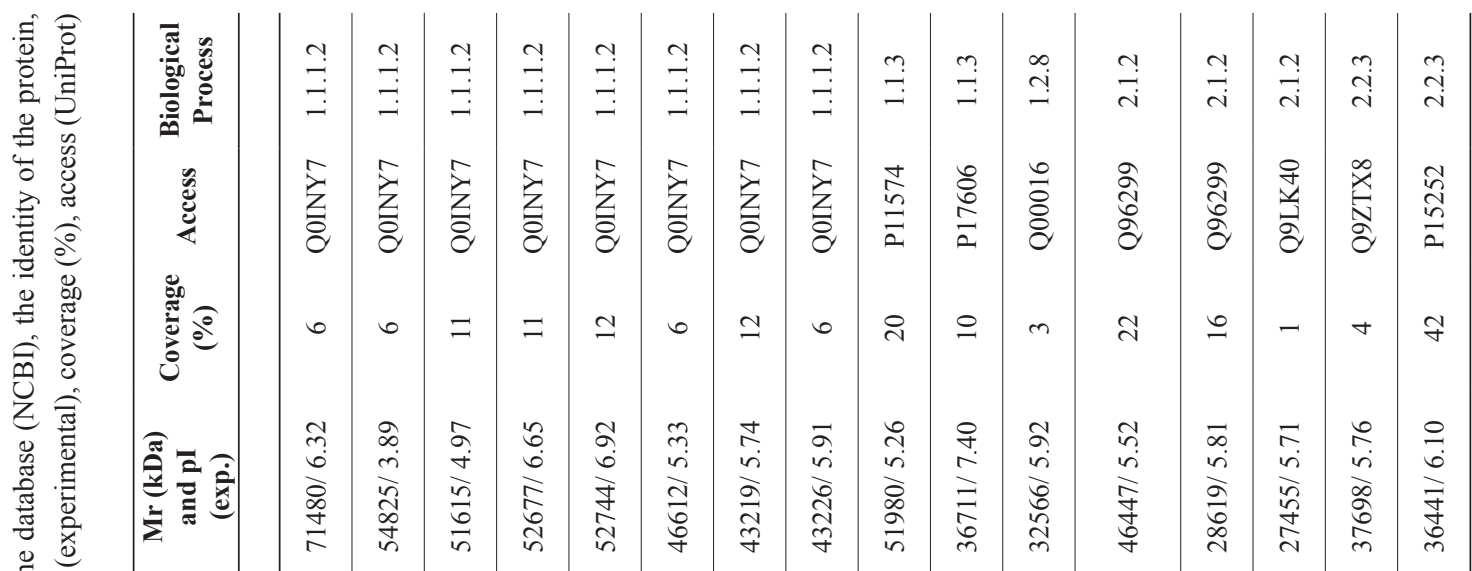

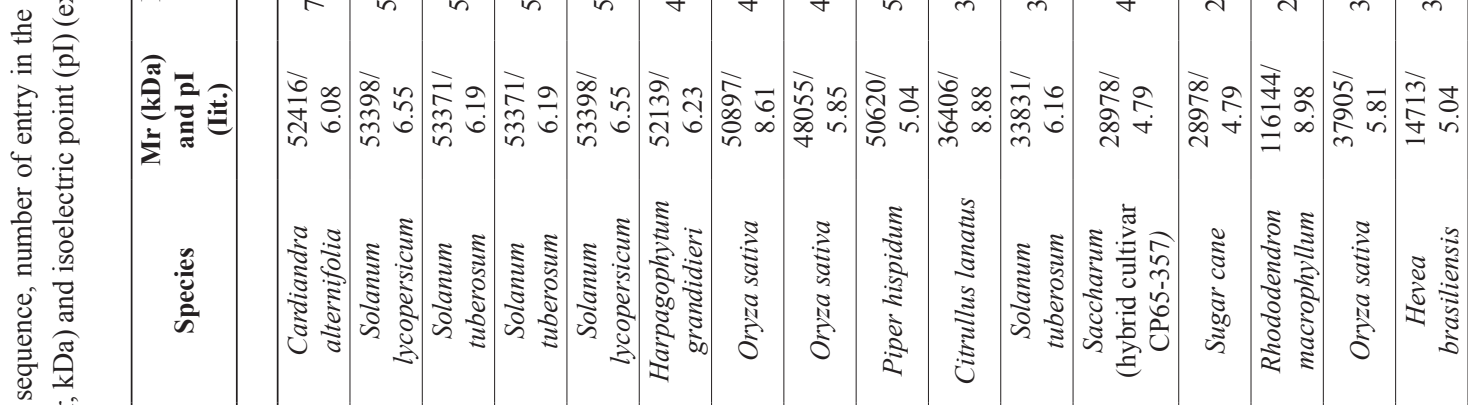

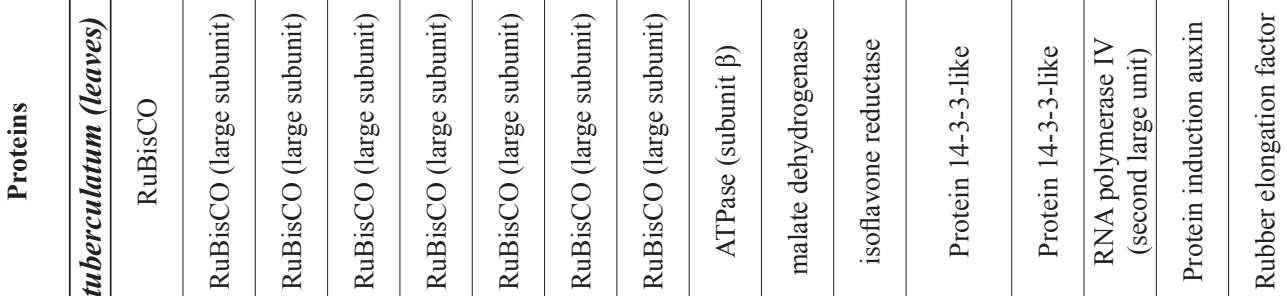
की 品

产 ๑ี 药

.ำ

퓽

흥

竞:

के है

节

离

范

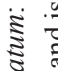

ปั)

इ

莒

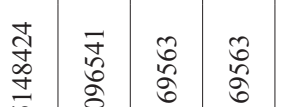

气 $\frac{n}{50}$

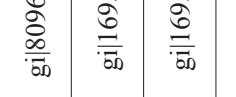

\section{寺空}

年 8

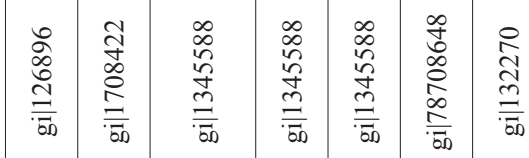

氙

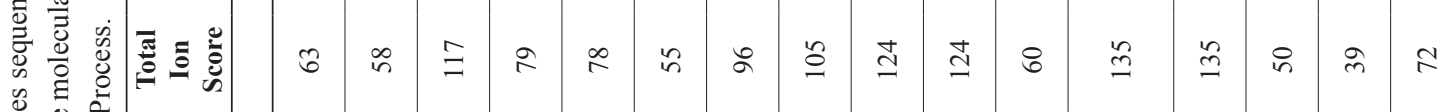

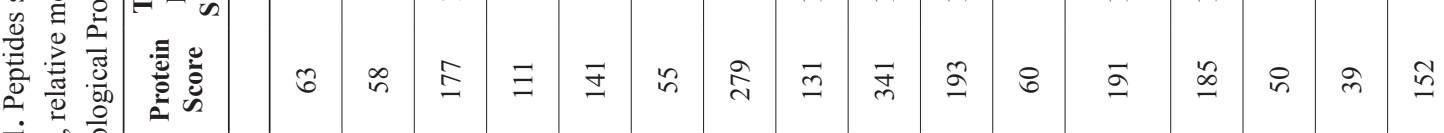

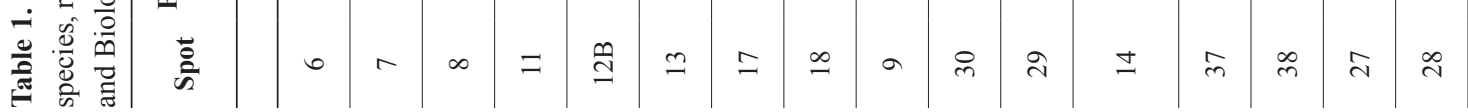




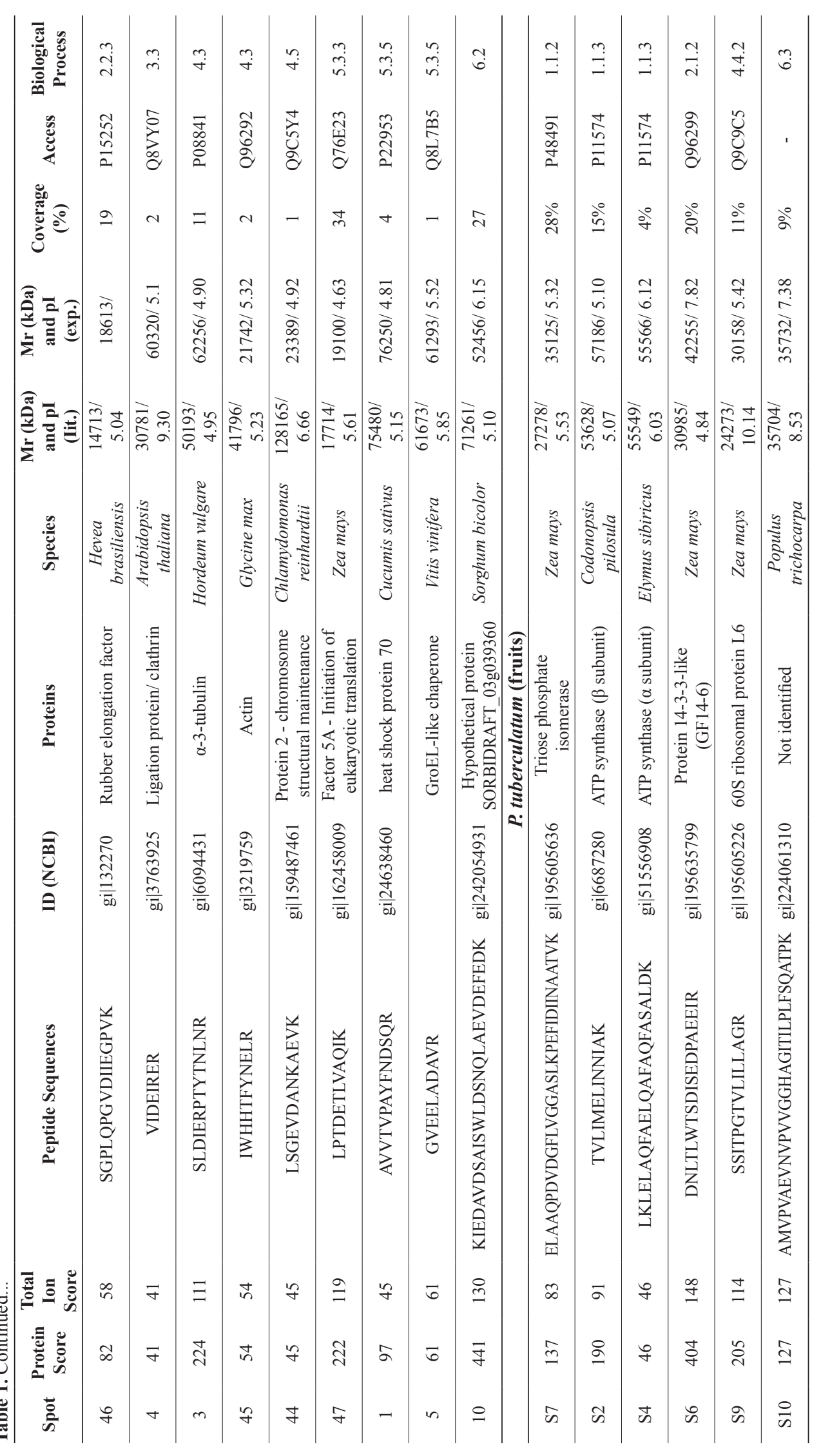


(9\%); Structure and Organization (9\%) and Miscellaneous (9\%), remaining $46 \%$ with no matches, classified as $N o$ Identity. Proteins from fruits gave no information about "information pathway" and "transport and signaling".

\section{Discussion}

Proteins identified from $P$. tuberculatum were mostly related to the primary metabolism. The enzymes involved in the cycle of carbon fixation, such as carbonic anhydrase and ribulose-1,5-bisphosphate carboxylase oxygenase (RuBisCO) were detected only in leaves fractions but not in fruits in spite of the presence of photosynthetic pigments. RuBisCO, identified in the leaves, is an enzyme involved in the Calvin cycle which catalyzes the first major atmospheric carbon fixation steps. This multimeric enzyme is also the most abundant protein in the leaves and the most abundant protein on earth (Kim et al., 2013). Given its importance in the biosphere, there are currently efforts to genetically engineer crop plants with more efficient RuBisCO. In plants, algae, cyanobacteria and phototrophic proteobacteria and chemoautotrophic organisms this enzyme normally consists of eight repetitions of two types of protein subunits, called large subunit (L, about $55 \mathrm{kDa}$ ) and small subunit (S, about $13 \mathrm{kDa}$ ) (Dhingra et al., 2004; Portis Júnior and Parry, 2007).

Isoflavone reductase-like (IFR) (spot 29 - P. tuberculatum leaves) is an oxidoreductase enzyme involved in the biosynthesis of isoflavones and catalyzes the reduction of NADPH-dependent. In rice (Oryza sativa), for example, it is suggested that isoflavone reductase (OsIRL) contribute as tolerance factor with damage caused by reactive oxygen species and also in grapefruit induced pathogen resistance (Yun et al., 2013).

The proteins 14-3-3 (spots 14 and 37 - leaves of P. tuberculatum; spot S6 - fruits of $P$. tuberculatum) were classified in the Cellular Process category. This is a large family of proteins which exist primarily as homo-and heterodimers in all eukaryotic cells. There is a high similarity of conservation and the sequence identity in all isoforms. 14-3-3 proteins are considered master regulators of many signal transduction cascades in eukaryotes and plants while their role is related to the processes of nutrients assimilation. Recent studies indicated that these proteins act on the metabolism of nitrogen, sulfur and phosphorus (Diaz et al., 2011; Shin et al., 2011).

In addition to 14-3-3 proteins, rubber elongation factor protein (REF) (spots 28 and 46 from leaves of $P$. tuberculatum) is an enzyme engaged in the rubber biosynthetic machinery. Natural rubber, an important macromolecule with many industrial uses, is produced by more than 2000 plant species distributed in four of the six dicotyledoneous super-orders. Several experimental evidences show that plants produce latex to protect themselves against predators attack. The rubber obtained from Hevea brasiliensis consists of long chains of cis-polyisoprene which are synthesized via the mevalonate pathway from acetyl CoA molecules derived from glycolysis. The polymerization of isopentenyl pyrophosphate (IPP) is assisted by REF which leads to long chains of cis-polyisoprene which form aggregates of rubber particles surrounded by a membrane lipoprotein (Priya et al., 2007). Despite of no isolation of rubber from Piper genus, several meroterpenes substituted with mono- or sesquiterpene chains were isolated. Prenyltransferases and REF share IPP and DMAPP as substrates in their enzymatic reactions, suggesting some analogy in their active sites.

Clathrin (spot 4 from leaves of $P$. tuberculatum) was classified in the Transport and Signaling category. It is best known for its role in membrane trafficking. Clathrin-coated vesicles are formed at the plasma membrane and the trans-Golgi network where they are involved in endocytosis and transport of secretory cargo, respectively. Recently was better defined the role of this protein in the function of the mitotic spindle (Royle, 2012).

Chaperones (spot 5 from leaves of $P$. tuberculatum) are included in the Structure and Organization category. They are proteins that act in signaling/transport of other proteins with impaired performance for the proteasome (protein breakdown) and assist the newly synthesized proteins to act properly. In addition to promoting the proper functioning of proteins, chaperones are also important to protect cells against the effects of high temperatures, especially under denaturating conditions (Santoro, 2000).

Heat shock proteins (HSPs) (spot 1 from leaves of $P$. tuberculatum) were classified in the Information Pathway category. HSPs are found in virtually all living organisms, from bacteria to humans (Wu, 1995). This family of proteins is named according to their molecular mass, and the HSP60, HSP70 and HSP90 refer to families of proteins with approximately 60,70 and $90 \mathrm{kDa}$, respectively (Srivastava, 2002). The increase concentration of HSPs can be triggered by exposure to different environmental stress conditions, such as infection, inflammation, exposure to toxins (metals, ultraviolet light, among others), nitrogen deficiency or water deprivation. Some HSPs proteins are expressed in low to moderate levels in all organisms, owing to their essential role in the maintenance of protein structure, or can be expressed in non-stressful conditions, simply for monitoring other cellular proteins. Several studies have demonstrated the role of HSPs in conferring tolerance stress in hybrid plants for agriculture (Vinocur and Altman, 2005).

The identification of all peptides had some complexity. Some were classified in the Miscellaneous category, because the MASCOT presented results as "unknown" or "not identified", ie, there are similar peptides sequences already reported in other plants, but with no functions as a protein assigned yet. Other analyzed peptides showed no similarity to any sequence in the database and were categorized as "no identity".

\section{Conclusions}

P. tuberculatum species is a non model plants, as well as Piper genus and Piperaceae family; therefore efforts devoted to add information about protein expression have great value. In this study proteins were characterized from 
leaves and fruits samples. The information obtained here certainly should contribute to the plant proteome database, which is still quite poor when compared to databases of other organisms. Some proteins/enzymes were identified as rubber elongation factor, isoflavone reductase, 14-3-3, catalase among others related to the processes of the organism's defense against biotic or abiotic processes. These data are the first information about the proteome of both species and will contribute to a better comprehension of the protein expression pattern in the Piperaceae family.

Our studies intend to contribute to expanding the range of biological information, enabling better understanding of the fundamental aspects of plant biology and may contribute in the future to agronomic practices using these species as model.

\section{Acknowledgements}

F.C. (07/56140-4), I.G.F.B. (09/00808-2) and S.N.L. (06/50086-5) wish to thank FAPESP for providing scholarships and fellowship, respectively. M.F. and M.J.K. are grateful to National Council for Scientific and Technological Development (CNPq) for research fellowships. M.F. and M.J.K. also gratefully acknowledge financial support from FAPESP (The State of Sao Paulo Research Foundation, grant \#2013/07600-3 and 2009/51850-9) and PRP-USP for fundings. S.N.L. thanks CONICET and ANPCyT from Argentina.

\section{References}

BAERENFALLER, K., GROSSMANN, J., GROBEI, M.A., HULL, R., HIRSCH-HOFFMANN, M., YALOVSKY, S., ZIMMERMANN, P., GROSSNIKLAUS, U., GRUISSEM, W. and BAGINSKY, S., 2008. Genome-scale proteomics reveals Arabidopsis thaliana gene models and proteome dynamics. Science, vol. 320, no. 5878, pp. 938-941. PMid:18436743. http:// dx.doi.org/10.1126/science.1157956.

BAGINSKY, S., KLEFFMANN, T., VON ZYCHLINSKI, A. and GRUISSEM, W., 2005. Analysis of shotgun proteomics and RNA profiling data from Arabidopsis thaliana chloroplasts. Journal of Proteome Research, vol. 4, no. 2, pp. 637-640. PMid:15822946. http://dx.doi.org/10.1021/pr049764u.

BALBUENA, T.S., DIAS, L.L.C., MARTINS, M.L.B., CHIQUIERI, T.B., SANTA-CATARINA, C., FLOH, E.I.S. and SILVEIRA, V., 2011. Challenges in proteome analyses of tropical plants. Brazilian Journal of Plant Physiology, vol. 1, no. 23, pp. 91-104. http:// dx.doi.org/10.1590/S1677-04202011000200001.

BRADFORD, M.M., 1976. A Rapid and sensitive method for quantitation of microgram quantities of protein utilizing principle of protein-dye binding. Analytical Biochemistry, vol. 72, pp. 248-254. PMid:942051. http://dx.doi.org/10.1016/0003-2697(76)90527-3.

BUSSELL, J.D., BEHRENS, C., ECKE, W. and EUBEL, H., 2013. Arabidopsis peroxisome proteomics. Frontiers in Plant Science, vol. 4, pp. 101. PMid:23630535.

CELEDON, P.A.F., ANDRADE, A., MEIRELES, K.G.X., CARVALHO, M.C.C.G., CALDAS, D.G.G., MOON, D.H., CARNEIRO, R.T., FRANCESCHINI, L.M., ODA, S. and LABATE, C.A., 2007. Proteomic analysis of the cambial region in juvenile Eucalyptus grandis at three ages. Proteomics, vol. 7, no. 13, pp. 2258-2274. PMid:17533644. http://dx.doi.org/10.1002/ pmic. 200600989.

COTINGUIBA, F., REGASINI, L.O., BOLZANI, V.S., DEBONSI, H.M., PASSERINI, G.D., CICARELLI, R.M.B., KATO, M.J. and FURLAN, M., 2009. Piperamides and their derivatives as potential anti-trypanosomal agents. Medicinal Chemistry Research, vol. 18, no. 9, pp. 703-711. http://dx.doi.org/10.1007/s00044-008-9161-9.

DHINGRA, A., PORTIS JUNIOR, A.R. and DANIELL, H., 2004. Enhanced translation of a chloroplast-expressed RbcS gene restores small subunit levels and photosynthesis in nuclear RbcS antisense plants. Proceedings of the National Academy of Sciences of the United States of America, vol. 101, no. 16, pp. 6315-6320. PMid:15067115. http://dx.doi.org/ 10.1073/pnas.0400981101.

DIAZ, C., KUSANO, M., SULPICE, R., ARAKI, M., REDESTIG, H., SAITO, K., STITT, M. and SHIN, R., 2011. Determining novel functions of Arabidopsis 14-3-3 proteins in central metabolic processes. BMC Systems Biology, vol. 5, p. 192. PMid:22104211. http://dx.doi.org/10.1186/1752-0509-5-192.

DURST, F., BENVENISTE, I., SCHALK, M. and WERCKREICHHART, D., 1996. Cinnamic acid hydroxylase activity in plant microsomes. Methods in Enzymology, vol. 272, pp. 259-268. PMid:8791785. http://dx.doi.org/10.1016/S0076-6879(96)72031-1.

GIAVALISCO, P., NORDHOFF, E., KREITLER, T., KLÖPPEL, K.D., LEHRACH, H., KLOSE, J. and GOBOM, J., 2005. Proteome analysis of Arabidopsis thaliana by two-dimensional gel electrophoresis and matrix-assisted laser desorption/ionisation-time of flight mass spectrometry. Proteomics, vol. 5, no. 7, pp. 19021913. PMid:15815986. http://dx.doi.org/10.1002/pmic.200401062.

GORDO, S.M.C., PINHEIRO, D.G., MOREIRA, E.C.O., RODRIGUES, S.M., POLTRONIERI, M.C., LEMOS, O.F., SILVA, I.T., RAMOS, R.T.J., SILVA, A., SCHNEIDER, H., SILVA JÚNIOR, W.A., SAMPAIO, I. and DARNET, S. 2012. High-throughput sequencing of black pepper root transcriptome. BMC Plant Bio, no. 12, p. 168. http://dx.doi.org/10.1186/14712229-12-168.

JOY, N., ASHA, S., MALLIKA, V. and SONIYA, E.V., 2013. De novo transcriptome sequencing reveals a considerable bias in the incidence of simple sequence repeats towards the downstream of pre-miRNAa of black pepper. PLoS One, vol. 8, no. 3, pp. e56694. PMid:23469176. http://dx.doi.org/10.1371/journal.pone.0056694.

KIM, Y.J., LEE, H.M., WANG, Y., WU, J., KIM, S.G., KANG, K.Y., PARK, K.H., KIM, Y.C., CHOI, I.S., AGRAWAL, G.K., RAKWAL, R. and KIM, S.T., 2013. Depletion of abundant plant RuBisCO protein using the protamine sulfate precipitation method. Proteomics, vol. 13, no. 14, pp. 2176-2179. PMid:23576416. http://dx.doi.org/10.1002/pmic.201200555.

NAVICKIENE, H.M., ALÉCIO, A.C., KATO, M.J., BOLZANI, V.S., YOUNG, M.C.M., CAVALHEIRO, A.J. and FURLAN, M., 2000. Antifungal amides from Piper hispidum and Piper tuberculatum. Phytochemistry, vol. 55, no. 6, pp. 621-626. PMid:11130674. http://dx.doi.org/10.1016/S0031-9422(00)00226-0.

PORTIS JÚNIOR, A.R. and PARRY, M.A., 2007. Discoveries in RuBisCO (Ribulose 1,5-bisphosphate carboxylase/oxygenase): a historical perspective. Photosynthesis Research, vol. 94, no. 1, pp. 121-143. PMid:17665149. http://dx.doi.org/10.1007/ s11120-007-9225-6.

PRIYA, P., VENKATACHALAM, P. and THULASEEDHARAN, A., 2007. Molecular cloning of rubber elongation factor protein cDNA from Hevea brasiliensis Muell. Arg. and its heterologous 
expression in Escherichia coli and Nicotiana tabacum. Current Science, vol. 93, no. 8, pp. 1077-1079.</jrn>

RAJ, L., IDE, T., GURKAR, A.U., FOLEY, M., SCHENONE, M., LI, X., TOLLIDAY, N.J., GOLUB, T.R., CARR, S.A., SHAMJI, A.F., STERN, A.M., MANDINOVA, A., SCHREIBER, S.L. and LEE, S.W., 2011. Selective killing of cancer cells with a small molecule targeting stress response to ROS. Nature, vol. 475, no. 7355, pp. 231-234. PMid:21753854. http://dx.doi.org/10.1038/ nature 10167.

REMMERIE, N., DE VIJLDER, T., LAUKENS, K., DANG, T.H., LEMIÈRE, F., MERTENS, I., VALKENBORG, D., BLUST, R. and WITTERS, E., 2011. Next generation functional proteomics in non-model plants: a survey on techniques and applications for the analysis of protein complexes and post-translational modifications. Phytochemistry, vol. 72, no. 10, pp. 1192-1218. PMid:21345472. http://dx.doi.org/10.1016/j.phytochem.2011.01.003.

RISON, S.C., HODGMAN, T.C. and THORNTON, J.M., 2000. Comparison of functional annotation schemes for genomes. Functional \& Integrative Genomics, vol. 1, no. 1, pp. 56-69. PMid:11793222. http://dx.doi.org/10.1007/s101420000005.

ROYLE, S.J., 2012. The role of clathrin in mitotic spindle organization. Journal of Cell Science, vol. 125, no. 1, pp. 19-28. PMid:22294613. http://dx.doi.org/10.1242/jcs.094607.

SANTORO, M.G., 2000. Heat shock factors and the control of the stress response. Biochemical Pharmacology, vol. 59, no. 1, pp. 55-63. PMid:10605935. http://dx.doi.org/10.1016/S00062952(99)00299-3.

SHIN, R., JEZ, J.M., BASRA, A., ZHANG, B. and SCHACHTMAN, D.P., 2011. 14-3-3 proteins fine-tune plant nutrient metabolism.
FEBS Letters, vol. 585, no. 1, pp. 143-147. PMid:21094157. http://dx.doi.org/10.1016/j.febslet.2010.11.025.

SILVA, R.V., NAVICKIENE, H.M.D, KATO, M.J., BOLZANI, V.S., MÉDA, C.I., YOUNG, M.C.M. and FURLAN, M., 2002. Antifungal amides from Piper arboreum and Piper tuberculatum. Phytochemistry, vol. 59, no. 5, pp. 521-527. PMid:11853747. http://dx.doi.org/10.1016/S0031-9422(01)00431-9.

SRIVASTAVA, P., 2002. Roles of heat-shock proteins in innate and adaptive immunity. Nature Reviews. Immunology, vol. 2, no. 3, pp. 185-194. PMid:11913069. http://dx.doi.org/10.1038/nri749.

VINOCUR, B.; ALTMAN, A. 2005. Recent advances in engineering plant tolerance to abiotic stress: achievements and limitations. Current Opinion in Biotechnology, vol. 16, no. 2. pp. 123-132.

WANKE, S., VANDERSCHAEVE, L., MATHIEU, G., NEINHUIS, C., GOETGHEBEUR, P. and SAMAIN, M.S., 2007. From forgotten taxon to a missing link? The position of the genus Verhuellia (Piperaceae) revealed by molecules. Annals of Botany, vol. 99, no. 6, pp. 1231-1238. PMid:17513306. http://dx.doi. org/10.1093/aob/mcm063.

WU, C., 1995. Heat shock transcription factors: structure and regulation. Annual Review of Cell and Developmental Biology, vol. 11, pp. 441-469. PMid:8689565. http://dx.doi.org/10.1146/ annurev.cb.11.110195.002301.

YUN, Z., GAO, H., LIU, P., LIU, S., LUO, T., JIN, S., XU, Q., XU, J., CHENG, Y. and DENG, X., 2013. Comparative proteomic and metabolomic profiling of citrus fruit with enhancement of disease resistance by postharvest heat treatment. BMC Plant Biology, vol. 13, no. 44, pp. 01-16. PMid:23497220. http://dx.doi. org/10.1186/1471-2229-13-44. 